Buana Sains Vol 18 No 1: 51 - 56, 2018

\title{
PENGOLAHAN DAN DAYA TAHAN LIMBAH PASAR SEBAGAI BAHAN PAKAN AYAM
}

\author{
Nonok Supartini dan Hariadi Darmawan \\ Program Studi Peternakan, Fakultas Pertanian, Universitas Tribhuwana Tunggadewi
}

\begin{abstract}
The aim of this research is to examine feed nutrients of market waste processed as hen feed supplementation and to identify the best processed of market waste as hen feed supplementation. This research held at Field Laboratory of Agriculture Faculty Tribhuwana Tunggadewi University, Tlogomas, Malang for processed the market waste and at Feed Nutrition of Animal Husbandry Faculty Brawijaya University, Veteran Street, Malang.

Materials used were vegetables and fish waste from the local market which classified in the waste group of green vegetables, tomatoes, sprouts and fish bone. Each of groups treated with under siege processed treatment, sun-dried processed treatment, boiled processed treatment and steamed process treatment. Each of group treatments used durability checked of feed supplementation by organoleptic inspection. This inspection is done for every 2 hours for 6 hours a day. This inspection is done in 20 days. The result concluded that under siege processed treatment of market waste was the best process for durability feed supplementation. The boiled processed treatment was the worst processed for durability feed supplementation.
\end{abstract}

Keywords: Market waste; processed; durability; feed supplementation.

\section{Pendahuluan}

Ayam kampung merupakan ayam asli Indonesia yang memiliki keunggulan pada produk dan fertilitasnya. Ayam kampung merupakan idola masyarakat sebagai ternak yang dipelihara, baik secara komersial maupun sebagai usaha sampingan. Pada pemeliharaan ayam kampung ini, ketersediaan bahan pakan menjadi salah satu kendala terbesar dalam penyusunan ransum mengingat tidak selalu ada dan beberapa bahan pakan harus diimpor. Salah satu solusi pemecahannya adalah penggunaan bahan pakan asal limbah, khususnya pemanfaatan limbah yang bermasalah di semua wilayah, yaitu limbah pasar. Limbah pasar merupakan bahan-bahan hasil sampingan dari kegiatan manusia yang berada di pasar dan banyak mengandung bahan organik, yang selanjutnya lebih banyak dikenal dengan sampah organik.

Sampah organik yang banyak terdapat dalam limbah pasar diantaranya adalah sampah-sampah hasil pertanian seperti sayuran, buah-buahan dan daundaunan serta dari hasil perikanan dan produk ternak. Sampah organik tersebut dapat dikelola menjadi bahan bakar atau sumber energi dan pakan ternak yang dapat lebih bernilai ekonomis dan lebih menguntungkan. Namun, perlu dikaji metode pengolahan yang terbaik, mengingat limbah pasar memiliki nilai nutrisi rendah yang ditunjukkan dengan tingginya kandungan serat kasar dan kadar air, walaupun (dalam basis kering) 
N. Supartini dan H. darmawan/ Buana Sains Vol 18 No 1 : 51-56

kandungan protein kasarnya cukup tinggi, yaitu berkisar antara 15-24 persen (Abun dkk., 2007). Tingginya kandungan protein kasar tersebut merupakan potensi yang dibutuhkan oleh ayam, meskipun di sisi lain, tingginya kadar air menyebabkan limbah pasar mudah busuk (Saenab, 2010). Untuk itu, dilakukan penelitian ini yang bertujuan untuk : (1) Mengetahui pengolahan limbah pasar sebagai bahan pakan ayam; (2) Mengetahui daya tahan terbaik limbah pasar yang diolah sebagai bahan pakan ayam.

\section{Metode Penelitian}

Penelitian ini difokuskan pada karakterisasi dan pengolahan dasar limbah pasar sebagai pakan ayam. Pengertian karakterisasi limbah pasar adalah pemilahan bahan limbah pasar berdasarkan kebutuhan energi dan protein ayam kampung untuk kemudian dianalisa proksimat. Setelah itu dilakukan pemilahan bahan limbah pasar yang tergolong sumber energi dan sumber protein. Hasil pemilahan tersebut kemudian diambil sebagai sampel menggunakan metode purpossive sampling (pengambilan sampel sesuai dengan tujuannya).

Pengambilan sampel ini untuk kepentingan analisa proksimat (kandungan nutrisi) lengkap. Analisa proksimat lengkap tersebut, meliputi analisa kandungan : bahan kering (BK), bahan organik (BO), serat kasar (SK), protein kasar (PK), lemak kasar (LK) dan Gross Energy (GE). Pada karakterisasi limbah pasar ini ditetapkan bahan limbah yang berasal dari limbah sayur dan limbah ikan, dengan proporsi 80\% limbah sayur dan 20\% limbah ikan. Limbah sayur yang dipilih adalah limbah sayuran berwarna hijau, tomat dan kulit kecambah. Limbah ikan yang dipilih adalah tulang kepala dan tulang ikan pada umumnya. Pengolahan dasar limbah pasar mengandung arti bahwa pada perlakuan ini dilakukan beberapa metode dasar pengolahan limbah pasar, mengingat limbah pasar bersifat bulky yang menyebabkan mudah busuk dan dapat menyebabkan acidosis (keracunan).

Penelitian ini dilaksanakan di : 1) laboratorium lapang Fakultas Pertanian (FP) Universitas Tribhuwana Tunggadewi Malang, selama 2 bulan (8 minggu); 2) Laboratorium Nutrisi dan Pakan Ternak Universitas Brawijaya Malang. Laboratorium lapang FP Universitas Tribhuwana Tunggadewi Malang digunakan untuk mengolah limbah pasar serta uji daya tahan pakan menggunakan uji organoleptik. Laboratorium Nutrisi dan Pakan Ternak Universitas Brawijaya Malang digunakan untuk melakukan analisa proksimat.

Pakan perlakuan adalah ransum dengan tingkat protein 17\%, yang disusun sendiri dan tersusun atas bahan : jagung kuning, polard, tepung daging, mineral, dl-metionin $2 \%$, lisyn $0,5 \%$ serta limbah pasar, terdiri atas limbah tomat, limbah kecambah, limbah sayur hijau, dan limbah ikan yang masing-masing diberikan dalam komposisi 3,75\%. Selain itu, juga digunakan pakan basal, sebagai pakan saat adaptasi ayam dengan lokasi penelitian. Penggunaan pakan basal tersebut disesuaikan dengan penggunaan pakan sebelumnya saat masih dipelihara supplier. Metode pengolahan dasar limbah pasar dijadikan sebagai perlakuan, yang terdiri dari metode : ditepung (P1), dijemur (P2), dikukus (P3) dan direbus (P4) dengan komposisi penambahan $15 \%$ (R1) dan komposisi penambahan $20 \%$ (R2). Pada perlakuan ini secara prinsip dilakukan analisa proksimat lengkap dan uji daya tahan. Selain itu, juga digunakan perlakuan kontrol yang merupakan $100 \%$ ransum tanpa penambahan olahan limbah pasar. 
N. Supartini dan H. darmawan/ Buana Sains Vol 18 No 1 : 51-56

Penelitian ini merupakan penelitian deskriptif dengan metode percobaan hayati menggunakan 9 perlakuan, yang dikelompokkan atas penggunaan olahan limbah pasar R1 dan R2 serta 4 metode pengolahan dasar yang diulang 3 kali (U). Variabel yang diukur dalam penelitian ini adalah kandungan nutrisi ransum perlakuan dan daya tahannya. Data yang diperoleh kemudian dianalisis menggunakan analisis data kuantitatif, mencakup analisis data deskriptif untuk menghitung nilai maksimum, nilai minimum, nilai rata-rata dan standar deviasi. Model analisis data penelitian ini dilakukan dengan cara mengumpulkan data dan menganalisis data kuantitatif, dengan prosedur : (1) Koding dan Tabulasi Data, yaitu memberi kode dan memeriksa data yang kemudian disusun sesuai dengan kelompok-kelompoknya atau kategori kategorinya dan dimasukkan ke dalam tabel distribusi frekuensi, dan matriksanalisis; (2) Editing data, yaitu mensortasi dan mengoreksi kesalahankesalahan pada waktu memasukkan data kedalam tabeltabel pengolahan data, (3) Interpretasi data, yaitu menjelaskan dan memberikan penafsiran pada data yang diolah.

\section{Hasil dan Pembahasan}

\section{Profil limbah pasar yang digunakan}

Pada penelitian ini digunakan limbah pasar Dinoyo, kota Malang. Adapun limbah pasar ini dipilih mengingat kedekatan dengan lokasi penelitian dan pasar tersebut masih merupakan salah satu pasar terpadu yang cukup ramai aktivitasnya. Limbah pasar sebenarnya merupakan kumpulan bahanbahan hasil sampingan dari kegiatan manusia yang berada di pasar dan banyak mengandung bahan organik, yang selanjutnya lebih banyak dikenal dengan sampah organik. Sampah organik tersebut dapat dikelola menjadi bahan bakar/sumber energi dan pakan ternak yang baik serta lebih bernilai ekonomis dan lebih menguntungkan. Menurut Hadiwiyoto (1983), sampah pasar yang banyak mengandung bahan organik adalah sampah hasil pertanian seperti sayuran, buah-buahan dan daun-daunan serta dari hasil perikanan dan peternakan.

Limbah pasar yang digunakan dalam penelitian ini terdiri atas limbah sayuran dan limbah ikan. Limbah sayur yang dipilih adalah limbah sayuran berwarna hijau, tomat dan kulit kecambah. Limbah ikan yang dipilih adalah tulang kepala dan tulang ikan pada umumnya. Limbah sayur yang dipilih disesuaikan dengan keberadaan paling banyak di pasar dan memiliki kandungan nutrisi yang dibutuhkan oleh ayam berdasarkan studi literatur. Limbah ikan digunakan sebagai sumber protein asal limbah pasar. Hal ini sesuai dengan pendapat Bestari dkk., (2011), yang menyatakan bahwa limbah pasar yang lebih berpeluang digunakan sebagai bahan pakan ternak adalah limbah sayuran karena selain ketersediaannya yang melimpah, limbah sayuran juga memiliki kadar air yang relatif lebih rendah jika dibandingkan dengan limbah buah-buahan sehingga jika limbah sayuran dipergunakan sebagai bahan baku untuk pakan ternak maka bahan pakan tersebut akan relatif tahan lama atau tidak mudah busuk dibandingkan limbah buah-buahan. Namun, Oomen (1984) menyatakan bahwa limbah sayuran mempunyai kecenderungan mudah mengalami pembusukan dan kerusakan, ditambah dengan tekstur limbah sayuran yang dinding selnya banyak mengandung serat kasar dengan ikatan ligno-selulosa, dapat mempengaruhi pemanfaatan protein dari material tersebut. Oleh karenanya, 
pengolahan fisik atau mekanis diperlukan untuk merenggangkan ikatan lignoselulosa.

\section{Proses pengolahan limbah pasar}

Pengolahan bahan pakan dapat dilakukan secara mekanis, kimiawi, ataupun biologis. Pada pelaksanaan penlitian ini dilakukan pengolahan secara mekanis, berupa pemasakan. Pemasakan dalam pengolahan pangan dikenal dengan istilah blansing, dan merupakan langkah pengawetan serta perenggangan ikatan fisik dinding sel tanaman. Pemasakan merupakan salah satu proses pengolahan panas yang sederhana dan mudah, dan dapat dilakukan dengan media air panas atau disebut perebusan maupun dengan uap panas atau disebut pengukusan (Ryanto,1991). Selain itu, pengolahan limbah pasar sebelum dimanfaatkan sebagai pakan ternak, oleh Saenab (2010), dinyatakan bahwa perlu dilakukan untuk menekan efek anti nutrisi yang umumnya berupa alkaloid dan untuk menonaktifkan enzim-enzim penyebab bau busuk yang ditimbulkan dari limbah sayuran. Upaya menonaktifkan enzim-enzim penyebab bau busuk tersebut dapat dilakukan dengan penjemuran dan pembuatan tepung limbah pasar.

Pada penelitian ini, dilakukan empat macam pengolahan limbah pasar sebagai bahan pakan ayam. Pengolahan tersebut, terdiri atas : ditepung (P1), dijemur (P2), dikukus (P3) dan direbus (P4). Pengolahan tersebut dikhususkan untuk limbah sayuran, sedangkan limbah ikan ditepung. Hal ini dilakukan mengingat, pengolahan limbah ikan yang paling aman sebagai bahan pakan ayam adalah ditepung. Sehingga, proses pencampuran antara limbah sayuran dan limbah ikan dilakukan setelah proses pengolahan. Proses pengolahan limbah sayuran secara prinsip memiliki kesamaan pada proses awal, yaitu dilakukannya proses pencucian kemudian ditiriskan dan dicacah sebelum dilakukan proses pengolahan selanjutnya.

Proses pengolahan ditepung, dilakukan dengan melanjutkan proses penirisan sampai dengan kering (tanpa sinar matahari atau pengering lainnya) yang dilanjutkan dengan proses penepungan dengan digiling halus. Proses ini berbeda dengan yang dilaksanakan oleh Abun dkk. (2007), yaitu dilakukan pengeringan langsung (dikeringkan, kemudian digiling menjadi tepung).

Proses pengolahan dijemur, dilakukan dengan melanjutkan proses penirisan dengan dijemur dibawah sinar matahari selama 4 jam. Proses pemanasan ini dilakukan untuk menurunkan kandungan asam amino, sebagaimana pendapat Maliyati dkk. (1992), yang menyatakan bahwa pemanasan umumnya menyebabkan terjadinya penurunan kandungan asam amino baik yang esensial maupun nonesensial. Selain itu, pemanasan selama 4 jam untuk menjaga terjadinya drip (pengeluaran cairan sel) secara berlebihan. Hal tersebut dikarenakan di saat drip, kandungan gizi termasuk protein yang terlarut atau yang telah berbentuk agregat-agregat ikut terbawa bersama drip.

Proses pengolahan dikukus dilakukan dengan melanjutkan proses penirisan dan kemudian dikukus diatas air mendidih selama lebih kurang 10 menit, selanjutnya ditiriskan dan didiamkan. Proses pengolahan direbus ini berbeda dengan yang dilakukan oleh Abun dkk. (2007), yaitu setelah pengkukusan dilakukan penjemuran dan penggilingan. Dalam hal ini bentuk limbah sayur yang dikukus pada penelitian ini berupa kukusan cacahan sayuran. 
N. Supartini dan H. darmawan/ Buana Sains Vol 18 No 1 : 51-56

Proses pengolahan direbus dilakukan dengan melanjutkan proses penirisan dan kemudian direbus dalam air mendidih selama lebih kurang 10 menit, selanjutnya ditiriskan dan didiamkan. Proses pengolahan direbus ini berbeda dengan yang dilakukan oleh Abun dkk. (2007), yaitu setelah perebusan dilakukan penjemuran dan penggilingan. Dalam hal ini bentuk limbah sayur yang direbus pada penelitian ini berupa rebusan cacahan sayuran.

\section{Daya tahan limbah pasar yang diolah}

Hasil olahan limbah pasar yang dikelompokkan sesuai dengan perlakuan, selanjutnya juga dilakukan pengamatan daya tahan. Pengamatan ini meliputi pemeriksaan organoleptik, yaitu : warna, bau, tekstur dan rasa. Perubahan atas pemeriksaan organoleptik, merupakan cemaran yang mengakibatkan tumbuhnya jamur dan kapang. Berdasarkan hasil pemeriksaan, maka dapat diketahui tingkat daya tahan olahan limbah pasar yang disajikan pada tabel 1 .

Tabel tersebut menunjukkan bahwa daya tahan terbaik pada P1, yaitu pengolahan limbah pasar dengan ditepung. Hal ini berkaitan dengan denauturasi protein. Protein yang belum terdenauturasi dapat menjadi prekursor tumbuhnya jamur dan kapang. Untuk itu, proses pemanasan dengan penepungan dapat mempercepat denauturasi protein sehingga daya tahannya bertambah. Dinyatak oleh Moelyanto (1984), bahwa gizi terutama protein dalam bahan pakan, mulai terkoagulasi pada temperatur sekitar $30^{\circ} \mathrm{C}$ dan terkoagulasi secara sempurna pada temperatur $60^{\circ} \mathrm{C}$, kemudian mulai terdenaturasi pada temperatur di atas $100^{\circ} \mathrm{C}$. Sedangkan daya tahan terburuk pada $\mathrm{P} 4$, yaitu pengolahan limbah pasar dengan direbus.

Tabel 1. Hasil Pemeriksaan Organoleptik Bahan Pakan Asal Olahan Limbah Pasar

\begin{tabular}{ccl}
\hline No. & Perlakuan & Deskripsi Perubahan dan Daya Tahan Bahan Pakan Limbah \\
Pasar
\end{tabular}

Keterangan : semua bahan perlakuan ditempatkan pada plastik tertutup dan terjaga daris sinar matahari, tetesan air dan kelembaban tanah 


\section{Kesimpulan}

Hasil yang dicapai dan pembahasan tersebut, melandasi kesimpulan dari penelitian ini, yaitu :

1. Limbah pasar dapat diolah menjadi bahan pakan ayam melalui pengolahan : ditepung, dijemur, direbus dan dikukus

2. Daya tahan terbaik pengolahan limbah pasar adalah dengan ditepungkan, sedangkan daya tahan terjelek pengolahan limbah pasar adalah dengan direbus

\section{Daftar Pustaka}

Abun, D. Rukmana, dan D. Saefulhadjar., 2007. Efek Pengolahan Limbah Sayuran Secara Mekanis terhadap Nilai Kecernaan pada Ayam Kampung Super JJ-101. Jurnal Ilmu Ternak, Desember 2007, Vol. 7 No. 2, 81 - 86

Fatiha S. 2012. Perubahan Bahan kering Serta Produksi Gas, Campuran Limbah Organik Pasar Yang Difermentasikan Dengan Imbangan Berbeda. Fakultas Peternakan Universitas Hasanuddin, Makassar.

Ishak, E dan S. Amrullah. 1985. Ilmu Pangan dan Teknologi Pangan. Penerbit badan Kerjasama Perguruan tinggi Negeri Indonesia Bagian Timur, Makassar.

Oomen. 1984. Komposisi Beberapa Jenis Limbah Sayuran. Fapet IPB. Bogor.

Saenab, Andi, 2010. Evaluasi Pemanfaatan Limbah Sayuran Pasar Sebagai Pakan Ternak Ruminansia di DKI Jakarta. Balai Pengkajian Teknologi Jakarta. 